\title{
Revision of Phaeochiton Kerzhner, 1964 (Heteroptera: Miridae: Phylini)
}

\author{
FEDOR V. KONSTANTINOV \\ St. Petersburg State University, Department of Entomology, Universitetskaya nab. 7/9, 199034 St. Petersburg, Russia; \\ e-mail: fkonstantinov@hotmail.com
}

Key words. Heteroptera, Miridae, Phylini, Phaeochiton, revision, taxonomy, new species, key, Mongolia

\begin{abstract}
The genus Phaeochiton Kerzhner, 1964 is revised and P. alenae sp. n. from Mongolia is described. Differential diagnoses are provided for the genus and its three species. Illustrations of male and female genitalia, tarsus and pretarsus, photographs of the dorsal habitus, hosts, and distributional records of the species discussed are given.
\end{abstract}

\section{INTRODUCTION}

The tribe Phylini is one of the largest and confusing groups of plant bugs, with many genera lacking adequate diagnoses. In the Palearctic region the tribe is represented by more than 1000 species from 134 genera (Kerzhner \& Josifov, 1999). The group is host-specific, phytophagous and very speciose in grassy steppes, shrublands, saline lands, and deserts of the Mediterranean region and Central Asia.

Phaeochiton Kerzhner, 1964 was originally described as a subgenus of Heterocapillus Wagner, 1960, which in turn was initially treated as a subgenus of Atractotomus Fieber, 1858. The latter genus has a highly complex taxonomic history and for a long time was recognized almost solely on the basis of the enlarged second antennal segment, presence of scale-like setae on dorsum and strongly declivent head without produced clypeus (Wagner, 1952; Carvalho, 1955; Wagner \& Weber, 1964).

The original diagnosis of the subgenus Heterocapillus was based on the dorsal vestiture having three distinct types of setae and a vesica with one or two well developed apical blades and the secondary gonopore located far from the apex of vesica (Wagner, 1960). Atractotomus s. str. was diagnosed by Wagner as having two types of setae on the dorsum and the secondary gonopore located subapically. Subsequently Kerzhner (1962) upgraded Heterocapillus to generic rank without altering the diagnosis.

The subgenus Phaeochiton was described by Kerzhner (1964) to accommodate the single species $H$. caraganae Kerzhner, 1964 and distinguished it from Heterocapillus by the latter having a distinctly thickened, fusiform second antennal segment in both sexes, the presence of dark setae on the pronotum, uniformly black body coloration and vesica with two apical blades. Later Putshkov (1977) upgraded Phaeochiton to generic rank and described P. ebulum Putshkov, 1977. He did not augment the diagnosis of the genus and indicated that $P$. caraganae somewhat resembles Heterocapillus spp. in the fusiform second antennal segment of females and the color-pattern of the tibiae of both sexes.
Stonedahl (1990) provided a discussion on the taxonomy of Heterocapillus in his detailed revision of Atractotomus Fieber, 1858. In particular, he indicated that the thickness of the second antennal segment is too highly variable to be used as a diagnostic feature at the generic level. Stonedahl also noted that at least two groups of species can be recognized within Heterocapillus, with $H$. pici (Reuter, 1899) together with Atractotomus amygdali Wagner, 1960, A. mali (Meyer-Dür, 1843), A. rhodani Fieber, 1861, and A. vireti Wagner, 1955 apparently forming a distinct monophyletic group. The four latter species were treated by Stonedahl as incertae sedis and referred to as the A. mali complex. Kerzhner \& Matocq (1994) subsequently investigated the lectotype of $A$. vireti and synonymized this species with $A$. mali.

Pagola-Carte et al. (2006) provided detailed illustrations and noted great similarity in the structure of the vesica between Atractotomus amygdali and Psallus (Mesopsallus) ambiguus (Fallén, 1807). These authors also credited Wyniger (2004) who conducted cladistic analyses of Psallus spp. and noted that the resulting phylogeny does not provide any information on the relationship of $P$. ambiguus to the other species under study.

Thus, the monophyly of Heterocapillus is currently corroborated almost solely by the dorsal vestiture composed of three types of setae. An investigation of the relationships of Heterocapillus spp. with related genera, although highly desirable, is beyond the limits of the present study due to the limited material at hand. However, I doubt the suggestion that $H$. pici is a member of the A. mali complex. The former species differs from the $A$. mali complex in the shape of the vesical apical blade and the secondary gonopore located at a distance from the apex of the vesica.

In contrast to Heterocapillus, the monophyly of Phaeochiton is well corroborated by a number of characters of the pretarsus, vestiture, and especially male and female genitalia, listed in the proposed diagnosis and not shared by Heterocapillus spp. and related genera. The group is sufficiently distinct to warrant recognition at generic level and inclusion of any species currently assigned to Hetero- 
capillus would certainly make Phaeochiton nonmonophyletic.

The present paper provides the description of a new species, as well as a key to species, a revised diagnosis, and the redescription of the genus. A diagnosis, description, host and distributional information, a dorsal habitus photograph and illustrations of male and female genitalia are provided for each species of the genus.

\section{MATERIAL AND METHODS}

Bar code labels were attached to the specimens and are referred to as unique specimen identifiers (USIs). Generally each USI label corresponds to a single specimen; however, some USI labels correspond to two or three specimens in cases when several specimens are mounted on one pin. Please refer to the www.discoverlife.org website to access additional information, such as color photographs, specimens dissected, notes, collecting method, and specimens photographed for specimens examined in the Planetary Biodiversity Inventories Project on Plant Bugs and the present paper. The original locality data are given in square brackets, if different from the currently existing toponyms (see specimens examined).

All measurements are in millimeters (see Table 1). All scale bars are $0.05 \mathrm{~mm}$. The vesica is figured in lateral and ventral views which are identical in all species and correspond to the right side and ventral views of the vesica located in the body of the insect. All explanations of terminology used for the description of the vesica are given in the Figs 13, 15. All specimens examined in the course of this study, including types, are retained at the Zoological Institute, St. Petersburg.

\section{TAXONOMY}

\section{Phaeochiton Kerzhner, 1964}

Phaeochiton Kerzhner, 1964: 128 (as subgenus of Heterocapillus; upgraded by V.G. Putshkov, 1977: 370). Type species by monotypy: Heterocapillus caraganae Kerzhner, 1964.

\section{Diagnosis}

Recognized among other Phylini by the following combination of characters: vestiture composed of narrow, apically acuminate silver scale-like setae densely distributed on dorsum, sometimes also ventrally, and simple silver setae, sometimes darkened on apical part of forewing; second antennal segment cylindrical in males, cylindrical or fusiform in females; pretarsus with thin and straight, slightly medially curved claw, pulvillus narrow and relatively small, covering at most half of ventral surface of claw (Figs 19, 20); genital capsule with low ventro-apical keel; body of S-shaped vesica with distinctive curvature and form reminiscent of Europiella spp., with several closely approximating ridges running along margin of lateral strap, and with a portion of one strap terminating near secondary gonopore (Figs 13-16, 21, 22, 27, 28), apical portion of vesica with one or two blades of unequal length, smaller blade, if present, straight, nearly cylindrical, with apical incision or denticle (Figs 28-31), larger blade somewhat flattened, more or less smoothly curved and gradually tapering; secondary gonopore removed from apex of vesica, placed on membrane, large, with well developed sculpture; bursa copulatrix with comparatively small ovoid sclerotized rings (Figs 32-34); vestibulum narrow, S-shaped (Figs 32, 37).
The closely related genus Heterocapillus is separated from Phaeochiton by the presence of dark suberect spinelike setae on dorsum, typically located on cuneus and at sides of pronotum and hemelytra, the short claw with broad base and strongly bent apex (Figs 17, 18), the large pulvillus far surpassing half the length of claw, the genital capsule without keel, the body of vesica without ridges along lateral strap and without portion of one strap terminating near secondary gonopore (see Figs 711-712A in Wagner, 1975), the unusually large sclerotized rings, and the $\mathrm{C}$-shaped vestibulum with laterally directed opening (Figs 35, 36).

\section{Description}

Male. Macropterous, with somewhat elongate body, total length 3.7-5.5.

TABLE 1. Measurements (mm).

\begin{tabular}{|c|c|c|c|c|c|c|c|c|}
\hline \multirow{2}{*}{\multicolumn{2}{|c|}{ Species }} & \multicolumn{4}{|c|}{ Length } & \multicolumn{3}{|c|}{ Width } \\
\hline & & Body & $\begin{array}{l}\text { Cun- } \\
\text { Clyp }\end{array}$ & $\begin{array}{c}\text { Pro- } \\
\text { notum }\end{array}$ & $\begin{array}{l}\text { Ant- } \\
\text { Seg2 }\end{array}$ & Head & $\begin{array}{c}\text { Pro- } \\
\text { notum }\end{array}$ & $\begin{array}{l}\text { Inter } \\
\text { OcDi }\end{array}$ \\
\hline \multicolumn{9}{|l|}{ P. alenae } \\
\hline \multirow[t]{5}{*}{$\widehat{\partial}(\mathrm{N}=10)$} & Mean & 5.07 & 4.26 & 0.75 & 1.31 & 0.91 & 1.57 & 0.44 \\
\hline & SD & 0.27 & 0.19 & 0.05 & 0.13 & 0.03 & 0.06 & 0.01 \\
\hline & Range & 0.95 & 0.73 & 0.20 & 0.38 & 0.08 & 0.23 & 0.03 \\
\hline & Min & 4.60 & 3.90 & 0.63 & 1.05 & 0.88 & 1.43 & 0.43 \\
\hline & Max & 5.55 & 4.63 & 0.83 & 1.43 & 0.95 & 1.65 & 0.45 \\
\hline \multirow[t]{5}{*}{ 우 $(\mathrm{N}=10)$} & Mean & 4.46 & 3.87 & 0.74 & 1.20 & 0.91 & 1.55 & 0.49 \\
\hline & SD & 0.27 & 0.20 & 0.02 & 0.07 & 0.03 & 0.07 & 0.01 \\
\hline & Range & 0.80 & 0.70 & 0.08 & 0.20 & 0.08 & 0.20 & 0.03 \\
\hline & Min & 4.00 & 3.50 & 0.70 & 1.10 & 0.88 & 1.45 & 0.48 \\
\hline & Max & 4.80 & 4.20 & 0.78 & 1.30 & .95 & 1.65 & 0.50 \\
\hline \multicolumn{9}{|c|}{ P. caraganae } \\
\hline \multirow[t]{5}{*}{ ô $(\mathrm{N}=10)$} & Mean & 4.27 & 3.59 & 0.73 & 1.29 & 0.89 & 1.41 & 0.41 \\
\hline & SD & 0.25 & 0.18 & 0.04 & 0.10 & 0.03 & 0.09 & 0.02 \\
\hline & Range & 0.80 & 0.63 & 0.13 & 0.28 & 0.08 & 0.28 & 0.08 \\
\hline & Min & 3.90 & 3.30 & 0.65 & 1.15 & 88 & 1.28 & 0.38 \\
\hline & Max & 4.70 & 3.93 & 0.78 & 1.43 & 95 & 1.55 & 0.45 \\
\hline \multirow[t]{5}{*}{ 우 $(\mathrm{N}=10)$} & Mean & 4.16 & 3.66 & 0.74 & 1.34 & 91 & 1.44 & 0.47 \\
\hline & SD & 0.17 & 0.08 & 0.02 & 0.06 & 0.02 & 0.06 & 0.01 \\
\hline & Range & 0.60 & 0.25 & 0.08 & 0.19 & 0.05 & 0.18 & 0.03 \\
\hline & Min & 3.80 & 3.50 & 0.70 & 1.23 & 0.88 & 1.35 & 0.45 \\
\hline & Max & 4.40 & 3.75 & 0.78 & 1.41 & 0.93 & 1.53 & 0.48 \\
\hline \multicolumn{9}{|l|}{ P. ebulum } \\
\hline \multirow[t]{5}{*}{ đิ $(\mathrm{N}=10)$} & Mean & 4.06 & 3.44 & 0.54 & 1.08 & 0.80 & 1.21 & 0.39 \\
\hline & SD & 0.22 & 0.12 & 0.02 & 0.05 & 0.00 & 0.08 & 0.01 \\
\hline & Range & 0.60 & 0.38 & 0.08 & 0.15 & 0.01 & 0.25 & 0.03 \\
\hline & Min & 3.70 & 3.20 & 0.50 & 1.00 & 0.80 & 1.05 & 0.38 \\
\hline & Max & 4.30 & 3.58 & 0.58 & 1.15 & 0.81 & 1.30 & 0.40 \\
\hline \multirow[t]{5}{*}{ ㅇ $(\mathrm{N}=10)$} & Mean & 3.37 & 2.96 & 0.50 & 0.96 & 0.80 & 1.16 & 0.44 \\
\hline & $\mathrm{SD}$ & 0.20 & 0.15 & 0.03 & 0.05 & 0.02 & 0.06 & 0.02 \\
\hline & Range & 0.70 & 0.43 & 0.09 & 0.15 & 0.06 & 0.18 & 0.05 \\
\hline & Min & 3.00 & 2.75 & 0.45 & 0.93 & 0.76 & 1.08 & 0.40 \\
\hline & Max & 3.70 & 3.18 & 0.54 & 1.08 & 0.83 & 1.25 & 0.45 \\
\hline
\end{tabular}




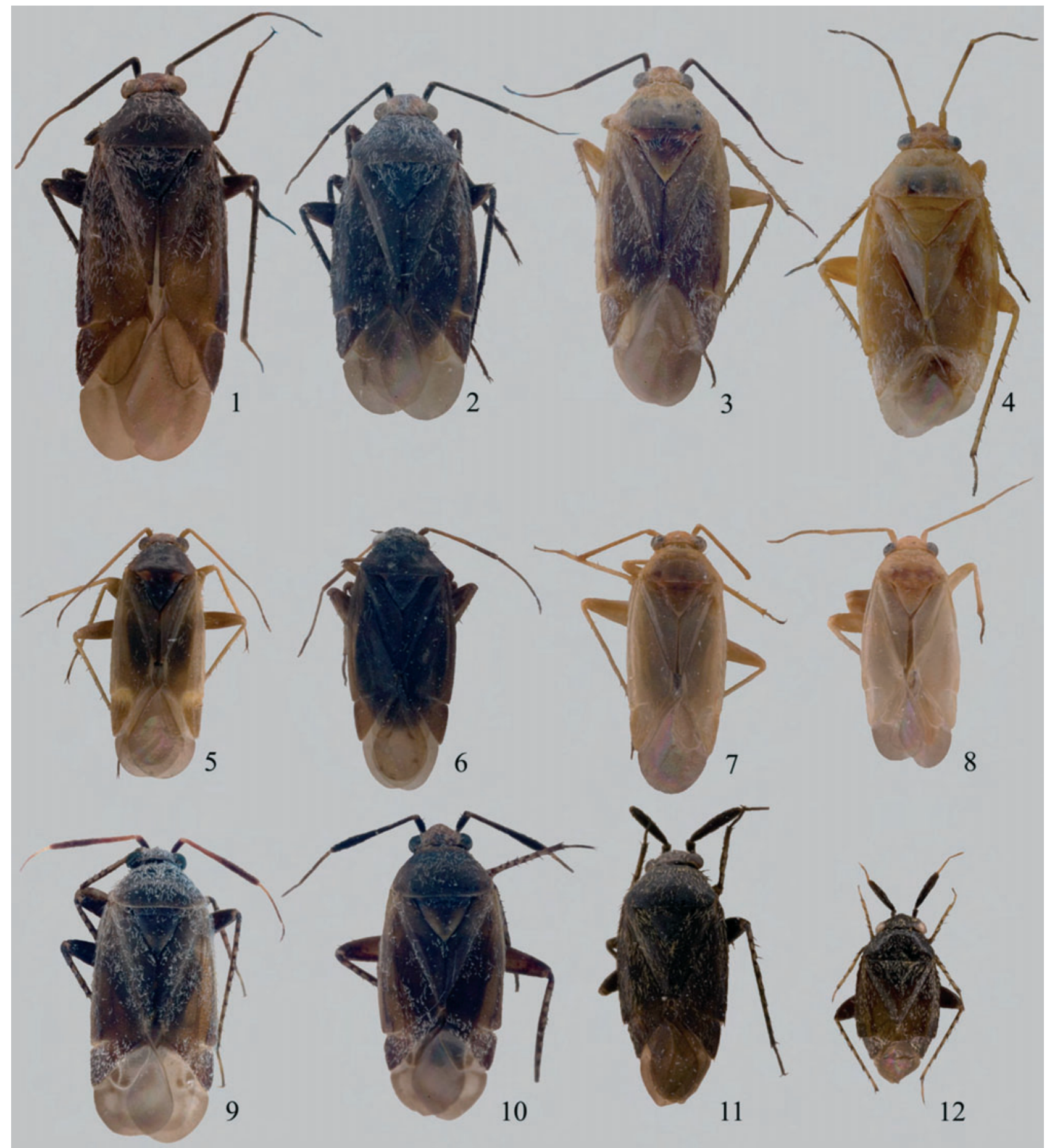

Figs 1-12. Dorsal habitus of Phaeochiton and Heterocapillus spp. 1-4. P. alenae: $1-\hat{\delta}$, AMNH PBI 00222448; $2-q$, AMNH_PBI 00222481; $3-\delta$, AMNH_PBI 00222383; $4-$ o, AMNH_PBI 00222371. 5-8. P. ebulum: 5 - §, AMNH_PBI 00222142; $6-q$, AMNH PBI 00222303; $7-\widehat{0}$, AMNH PBI 00222144; $8-$ + , AMNH PBI 00222231; 9-10. P. caraganae: $9-$

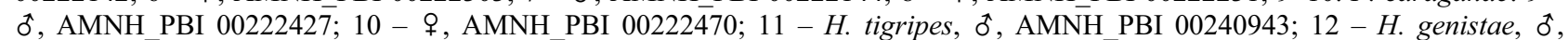
AMNH_PBI 00240950.

Coloration: Variable (Figs 1-10), dorsum and venter ranging from dark brown to pale yellow, usually uniform, without contrasting spots, vertex invariably pale even in darkest specimens; tibia with darkened ventral surface, large dark spots at bases of tibial spines and darkened base of tibia in $P$. caraganae, uniformly colored in other species, membrane pale brown. Surface and vestiture: Dorsum smooth, moderately shining; with dense simple silver setae, usually darkened on cuneus and apical parts of corium, and narrow, moderately flattened, apically acuminate scale-like silver setae, in $P$. caraganae scalelike setae also distributed on venter; appendages with simple semierect pale setae, first antennal segment with two dark, rarely pale brown, medial spines, each femur with a few dark spines apically, tibial spines dark brown to black, rarely pale brown. Structure: Head: Moderately 


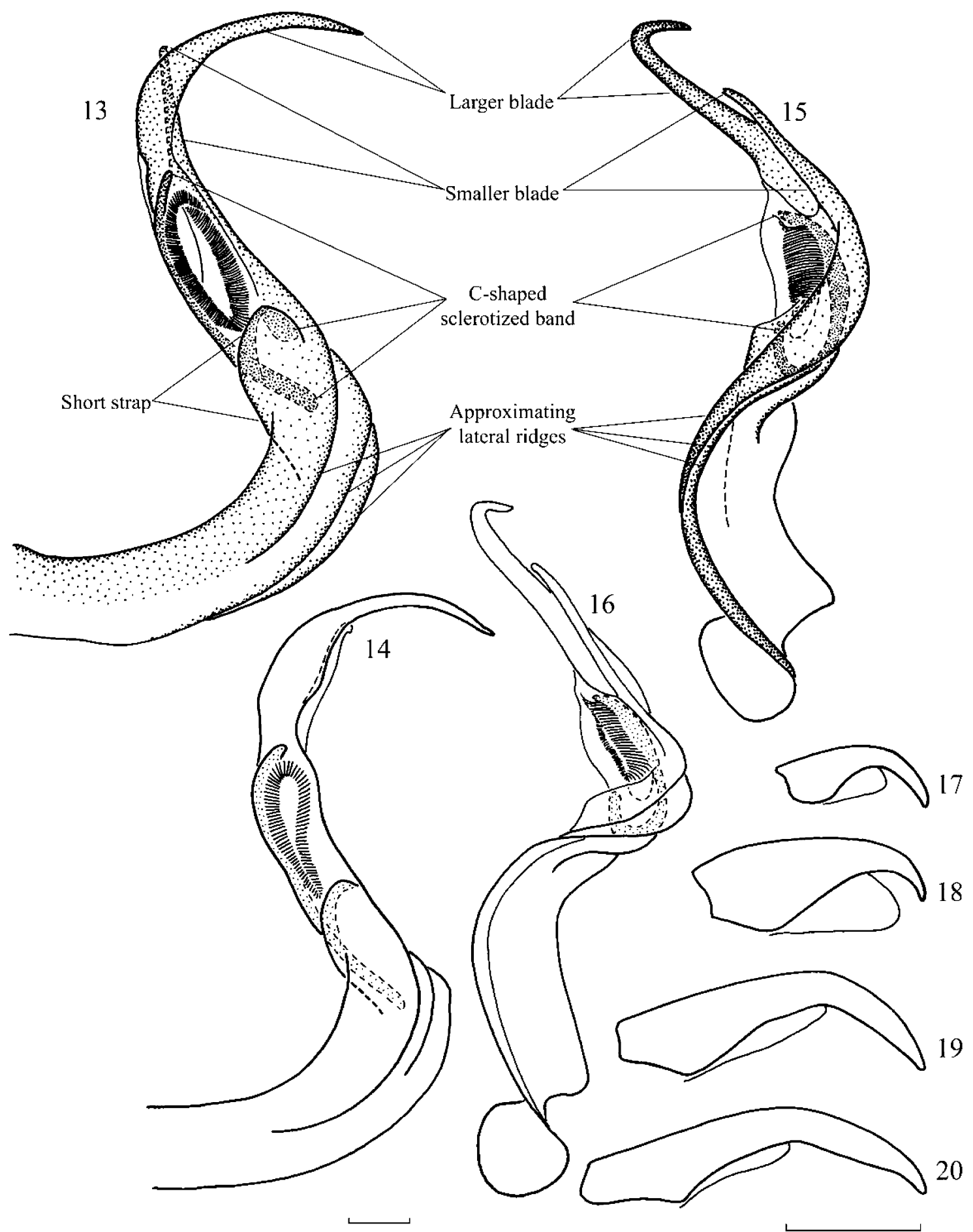

Figs 13-20. Vesica and claws of Phaeochiton and Heterocapillus spp. 13-16. Vesica of P. alenae: 13, 15 - normally sclerotized vesica, AMNH_PBI00222406; 14, 16 - teneral vesica, AMNH_PBI00222397; 13, 14 - lateral view; 15, 16 - ventral view. 17-20. Claws: $17-H$. genistae, AMNH_PBI00240950; $18-$ H. tigripes, AMNH_PBI00240943; 19 - P. alenae, AMNH_PBI00222388; 20 - P. caraganae, AMNH_PBI00248997.

produced anteriorly in dorsal view; eyes relatively large, occupying at least three-fourths of height of head in lateral view, posterolateral margins of eyes contiguous with anterolateral margins of pronotum; vertex weakly convex, frons moderately sloping anteriorly in lateral view, clypeus weakly produced, usually not visible in dorsal view; antennae inserted near ventral margin of eye; second antennal segment linear; labium reaching from middle coxae to slightly beyond metacoxae. Thorax: Trapezoidal, about twice as broad as long, disk weakly convex, calli indistinct, posterior margin nearly straight or weakly concave medially, lateral margins straight, posterolateral angles broadly rounded; mesonotum moderately exposed; metathoracic scent-gland evaporatory area broadly triangular, with distinctly elongated, posteriorly extended posterior angle. Legs: femur elongate, not swol- 


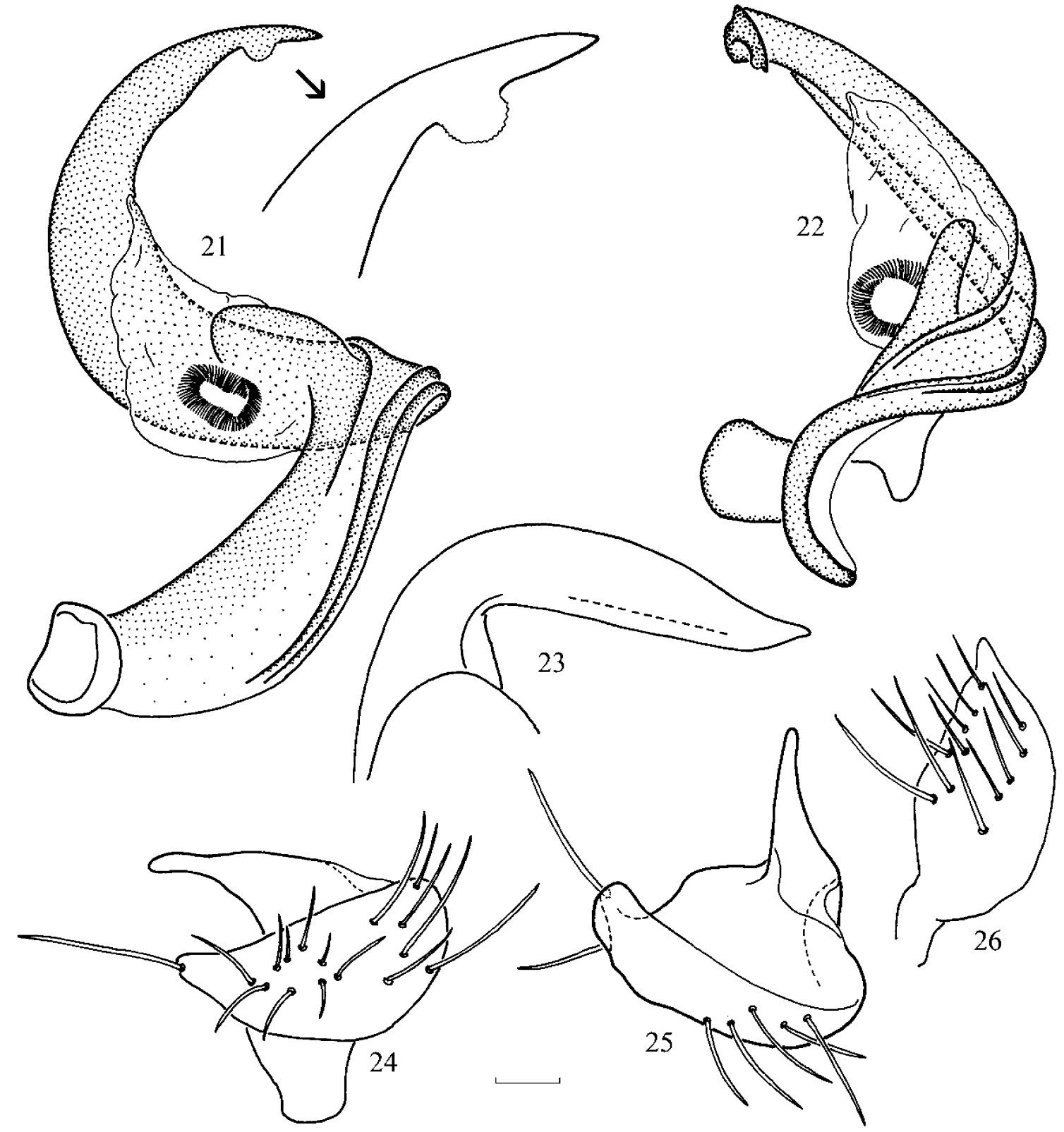

Figs 21-26. Male genitalia of Phaeochiton spp. 21-22. Vesica of P. caraganae, AMNH_PBI00222426: 21 - lateral view; 22 ventral view; 23-26. P. alenae, AMNH_PBI00222406: 23 - apex of theca; 24-25 - left paramere; 26 - right paramere.

len, usually slightly broader medially, tibia cylindrical, second and third tarsal segments of nearly equal length, claw (Figs 19, 20) thin, long and straight, moderately bent at middle, pulvillus small, barely reaching midpoint of claw, attached to the claw along whole length.

Genitalia: Genital capsule slightly less than half length of abdomen, distinctly longer than basal width, with low keel ventro-apically, and without distinctive ornamentation. Parameres: Right paramere lanceolate, of typical phyline shape (Fig. 26); left paramere (Figs 24, 25) with obtuse sensory lobe and straight, gradually tapering apical process. Apex of theca: Shape typical of many phylines (Fig. 23). Vesica: S-shaped, comparatively robust, body of vesica of distinctive curvature and form, with several closely approximating ridges running along margin of lateral strap, and with a portion of one strap terminating near secondary gonopore (Figs 13-16, 21, 22, 27, 28), apical portion of vesica with one or two blades of unequal length, smaller blade, if present, thin and straight, cylindrical, apically with incision or denticle (Figs 28-31), larger blade somewhat flattened, more or less smoothly curved and gradually tapering; secondary gonopore removed from apex and located at middle of vesica, placed on membrane lateral to sclerotized bands of vesica, large, with well developed sculpture.

Female. Macropterous. Similar to male in color, structure, and vestiture, but more strongly ovoid, and sometimes with slightly to strongly shortened hemelytral membrane; head projecting beyond eyes at about half head length, eyes slightly smaller than in male, with correspondingly broader vertex; second antennal segment usually linear, not dilated distally, but distinctly fusiform in $P$. caraganae. Genitalia: As in Figs $31-33$, with small 


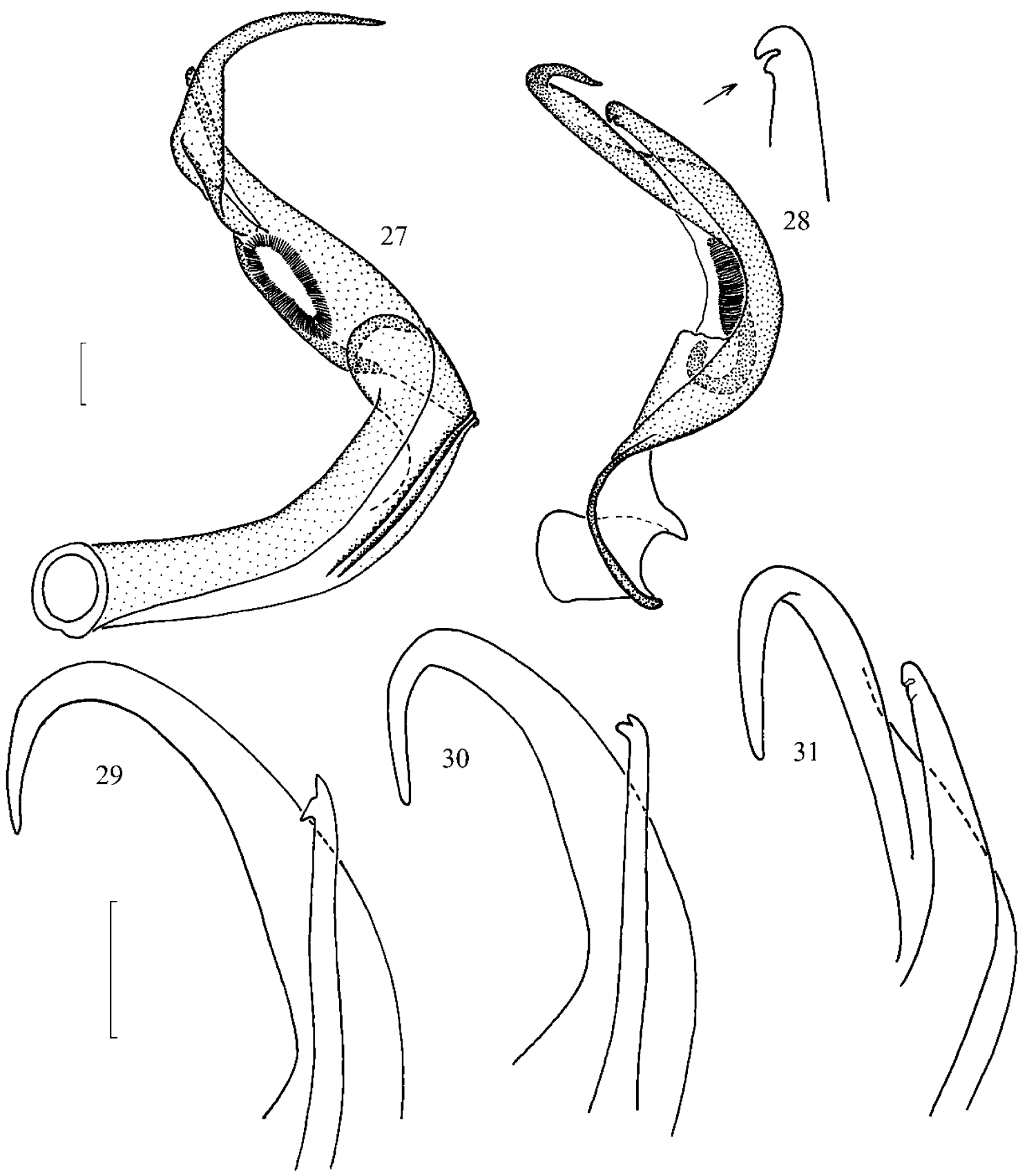

Figs 27-31. Vesica of Phaeochiton spp. 27-28. Vesica of P. ebulum: 27 - lateral view, AMNH_PBI00222379; 28 - ventral view, AMNH_PBI00222189; 29-31. Apical blades of vesica, ventro-lateral view: 29 - P. alenae, AMNH_PBI 00222401; 30 - P. alenae, AMNH_PBI 00222475; $31-P$. ebulum,AMNH_PBI 00222137.

ovoid sclerotized rings; posterior wall simple; vestibulum narrow, S-shaped, irregularly sclerotized (Fig. 36).

Hosts and natural history. Species of the genus are specialized feeders on Caragana spp. (Fabaceae). Kerzhner (1964) and Putshkov (1977) indicated that the duration of the adult stage is unusually short, only as long as two weeks for $P$. caraganae and $P$. ebulum. Judging by the label data, this seems to be also the case for $P$. alenae.

Distribution. Steppe zone of Palearctic.
Note. The ratio of specimens without fully developed, but membranous vesica is unusually high in all species of the genus across the distributional range. All such specimens have fully sclerotized exoskeleton, including the genital capsule and parameres, while the vesica remains soft but nonetheless possesses all the distinctive species specific features (Figs 14, 16). It seems likely, that this is due to the short duration of the adult life-span and specimens with membranous vesica were collected soon after the final molt. 

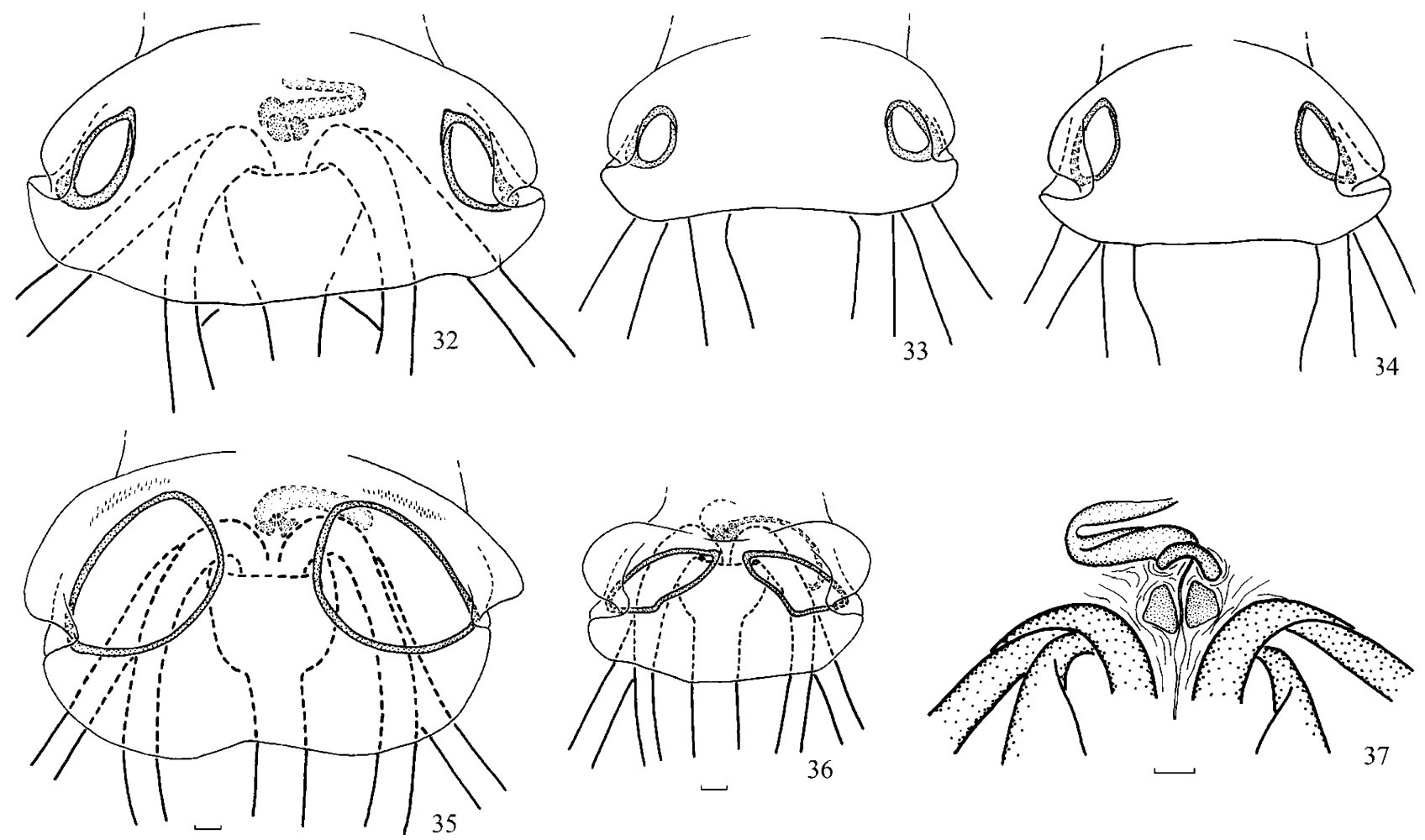

Figs 32-37. Female genitalia. 32-36. Bursa copulatrix and associated structures in dorsal view: $32-P$. alenae, AMNH_PBI 00222367; $33-P$. ebulum, AMNH_PBI 00222274; $34-P$. caraganae, AMNH_PBI 00248999; $35-H$. tigripes, AMNH_PBI 00240944; 36 - H. genistae, AMNH_PBI 00240953; 37 - vestibulum of $P$ alenae in ventral view, AMNH_PBI 00222367.

\section{Key to species}

1 Tibiae with darkened ventral surface, large dark spots at bases of tibial spines, and darkened tibial base (Figs 9, 10). Dorsum without dark simple setae, venter with narrow scale-like silver setae. Second antennal segment distinctly fusiform in females (Fig. 10). Vesica apically with single blade (Figs 21, 22)................. P. caraganae

2 Tibiae uniformly pale or dark brown, but without spots at bases of tibial spines (Figs 1-8). Dorsum with dark simple setae on cuneus and apical part of corium, venter with only simple silver setae. Second antennal segment linear in both sexes. Vesica apically with two blades. . . . . . . . . . . 3

3 Larger. Total length: males 4.6-5.6, females 4.0-4.8. Antennae completely dark brown or at least second antennal segment apically contrastingly brown, in a few females antennae entirely pale. Smaller blade of vesica thin, with slightly developed apical denticle (Figs 13-16, 29, 30). ... .

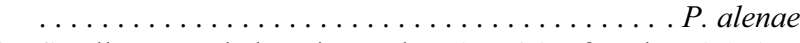

4 Smaller. Total length: males 3.7-4.3, females 3.0-3.7. Antennae uniformly pale yellow. Smaller blade of vesica more robust, nearly as wide as larger blade at base, with distinctly developed apical incision (Figs $27,28,31) \ldots \ldots \ldots$.

............................ ebulum

\section{Phaeochiton alenae sp. n.}

Figs 1-4, 13-16, 19, 23-26, 29, 30, 32, 37

\section{Diagnosis}

Recognizable by the large size, the uniform coloration of legs, the pattern of distribution of silver and dark simple setae on dorsum, and the twin-bladed vesica with thin, apically dentate smaller blade. Most similar to $P$. ebulum in the color-pattern, vestiture, and genital struc- ture, but differing in the shorter labium barely reaching middle coxa and other characters listed in the key.

\section{Description}

Male. Coloration (Figs 1-4): Dorsum and venter in specimens from Eastern Mongolia (Central, Suhbaatar, and East Govi Aimak) pale or dirty yellow, vertex, calli, and scutellum sometimes with orange tinge, second antennal segment and apex of labium always brown to black, first antennal segment somewhat darkened to completely pale, rarely base of scutellum and hemelytra somewhat darkened, femur with a series of minute pale brown markings apically, tarsus entirely or apically darkened, membrane uniformly smoky pale brown with dirty yellow veins (Figs 3, 4); body and appendages in specimens from Western Mongolia (Hovd and Dzavhan Aimak) uniformly dark brown, only vertex and frons dirty yellow (Figs 1, 2). Surface and vestiture: Dorsum with very dense simple setae, usually dark on cuneus and lateroapical part of corium and silver elsewhere, and narrow scale-like silver setae; medial spines of first antennal segment and apical spines of femur always dark, tibial spines dark brown to black. Structure: Total length 4.6-5.5, body $3.1-3.3 \times$ as long as width of pronotum. Head: Vertex 1.7-2.1 $\times$ as wide as eye; second antennal segment $0.7-0.9 \times$ as long as basal width of pronotum, $1.2-1.5 \times$ as long as width of head. Labium barely reaching middle coxa. Thorax: Pronotum 2.0-2.2 $\times$ as wide as long; tarsus and claw (Fig. 19) as in generic description. Genitalia: Genital capsule as in generic description. Parameres: Right paramere as in Fig. 26, 
about twice as long as wide; left paramere as in Figs 24, 25 , with obtuse sensory lobe and straight, gradually tapering, apical process. Apex of theca: As in Fig. 23. Vesica: with a portion of one strap terminating just proximal to secondary gonopore (Figs 13-16), apically with two blades of unequal length, smaller blade thin and straight, with minute denticle at apex (Figs 29, 30), larger blade hook-shaped, smoothly curved and gradually tapering; secondary gonopore in lateral view with C-shaped sclerotized band extending proximally along apical edge of shorter portion of one strap.

Female. Coloration, surface and vestiture: As in male, but usually somewhat paler. Structure: Body more ovoid, 2.7-3.1 $\times$ as long as width of pronotum; total length 4.0-4.8. Head: as in males but more prominent, with vertex wider, $2.1-2.6 \times$ as wide as eye; second antennal segment $0.7-0.8 \times$ as long as basal width of pronotum, $1.2-1.4 \times$ as long as width of head. Thorax: Pronotum 2.0-2.2 $\times$ as wide as long; tarsus and claw as in males. Genitalia: Bursa copulatrix as in Fig. 32, sclerotized rings ovoid, somewhat attenuated apically; vestibulum S-shaped, as in Fig. 37.

Hosts. Caragana bungei, C. spinosa, Caragana sp. (Fabaceae).

Distribution. Known from several localities in Mongolia. Etymology. Named for my wife Alena V. Tomilova.

Type material. Holotype: Mongolia: Central Aimak: $\mathrm{Nr}$ Songiin [Songino], SW of Ulaanbaatar, steppe, $47.81666^{\circ} \mathrm{N}$, 106.66666 ${ }^{\circ} \mathrm{E}$, 01.vii.1967, Emeljanov, $10^{\star}$ (AMNH_PBI 00249029). Paratypes: Mongolia: Central Aimak: Nr Songiin [Songino], SW of Ulaanbaatar, steppe, $47.81666^{\circ} \mathrm{N}$, 106.66666 ${ }^{\circ}$ E, 01.vii.1967, I.M. Kerzhner, Caragana bungei, $12 \sigma^{\star}$ (AMNH PBI 00222383-AMNH PBI 00222384, AMNH PBI 00222387-AMNH PBI 00222388, AMNH PBI 00222390-AMNH_PBI 00222396, AMNH_PBI 00222398), 26 우요 00222334-AMNH_PBI 01.vii.1967, Emeljanov, 10 (AMNH_PBI 00249030) Caragana bungei, 10 (AMNH_PBI 00222389). Dzavhan Aimak: $20 \mathrm{~km}$ W Somon Altay [Bayan-ula], $49.7^{\circ} \mathrm{N} 96.06666^{\circ} \mathrm{E}$, 02.vii. 1968 , Kozlov, 10 (AMNH_PBI 00222475), 29 (AMNH_PBI 00222475). East Govi Aimak: $15 \mathrm{~km} \mathrm{~S}$ of Hovsgol, 43.46666 ${ }^{\circ} \mathrm{N}, 109.63333^{\circ} \mathrm{E}$, 28.vi.1971, I.M. Kerzhner, $10^{\circ}$ (AMNH_PBI 00222411). Agaruut, $43.1667^{\circ} \mathrm{N}, 109.4333^{\circ} \mathrm{E}$, 27.vi.1971, A.F. Emeljanov, 20 (AMNH_PBI 00222412,

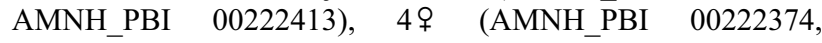
AMNH_PBI 00222375). Hovd Aimak: $15 \mathrm{~km}$ SW of Kobdo, $48.08333^{\circ} \mathrm{N}, 91.48333^{\circ} \mathrm{E}, 08 . v i .1980$, I.M. Kerzhner, Caragana spinosa, 20 (AMNH_PBI 00222446, AMNH_PBI 00222448), 13 을 (AMNH_PBI ${ }^{-}$00222477, AMNH_PBI 00222477, AMNH_PBI 00222477-AMNH_PBI 00222481). Altan-Hohiy Mts Range, $60 \mathrm{~km} \mathrm{~N}$ Myangat, $48.86666^{\circ} \mathrm{N}, 91.66666^{\circ} \mathrm{E}$, 04.viii.1970, A.F. Emeljanov, $10^{\Uparrow}$ (AMNH_PBI 00249031). Suhbaatar Aimak: Ongon-Els Sands, $15 \mathrm{~km}$ SSE Hongor, $45.664^{\circ} \mathrm{N}, 112.819^{\circ} \mathrm{E}$, 05.vii.1971-06.vii.1971, I.M. Kerzhner, Caragana sp., 39 (AMNH_PBI 00222371) Caragana sp., 320 (AMNH_PBI 00222399-AMNH_PBI 00222409), 39 우 (AMNH_PBI 00222360-AMNH_PBI 00222370, AMNH_PBI 00222372-AMNH_PBI 00222373, AMNH_PBI 00222405, AMNH_PBI 00222 410 ).

\section{Phaeochiton caraganae (Kerzhner, 1964)}

Heterocapillus (Phaeochiton) caraganae Kerzhner, 1964: 129.

Figs 9, 10, 20, 21, 22, 34

\section{Diagnosis}

Easily distinguished from other species in the genus by the darkened ventral surface of the tibia, the large dark spots at the base of the tibial spines, the vestiture with narrow scale-like silver setae on venter and without dark simple setae on dorsum, the distinctly fusiform second antennal segment in females and the single-bladed vesica apically with semicircular dentate outgrowth.

\section{Description}

Male. Coloration (Figs 9, 10): Dorsum and venter from olive-brown to dark brown, vertex pale brown, rarely pale, with a row of four dark markings, frons pale, with well developed series of dark rays radiating from midline, and sometimes with longitudinal dark spot along midline, clypeus with two narrow longitudinal stripes at sides, mandibular plates dark, first and second antennal segments dark brown, proximal half of second antennal segment sometimes paler than distal half, remaining segments pale yellow to pale brown. Anterior margin of pronotum usually and apex of scutellum rarely somewhat paler than remaining part of notum, labium apically darkened, hemelytra with pale claval suture, usually with pale edging along lateral margins of corium and cuneal fracture, membrane uniformly brown or with indistinctly bordered pale areas medially, veins whitish; thoracic pleura dirty yellow, mesothorax with dark brown spot dorsally; femora dirty yellow, with several series of rounded reddish brown to dark brown spots, dorsal surface gradually darkened apically and/or with dark stripes along fore and hind margins, ventral surface with brown-reddish subapical transverse band; tibia with darkened ventral surface, large dark spots at bases of tibial spines and darkened knees dorsally. Abdomen dirty yellow, with darkened genital segment. Surface and vestiture: Dorsum and venter with more or less uniform mixture of narrow scale-like and simple silver setae, without darkened simple setae; medial spines of first antennal segment, apical spines of femur and tibial spines dark brown to black. Structure: Total length 3.9-4.7, body 3.0-3.2 $\times$ as long as width of pronotum. Head: Vertex $1.5-1.7 \times$ as wide as eye; second antennal segment thick, cylindrical or barely incrassate, nearly as wide as first segment, twice as wide as third and fourth segments, $0.9-1.0 \times$ as long as basal width of pronotum, $1.3-1.6 \times$ as long as width of head, labium reaching to or slightly surpassing metacoxae. Thorax: Pronotum $1.8-2.1 \times$ as wide as long; tarsus and claw (Fig. 20) as in generic description. Genitalia: Genital capsule as in generic description. Parameres: Right paramere rather long, body of paramere about 2.5 times as long as broad; apical process of left paramere longer than in other species of the genus, sensory lobe somewhat longer and distinctly narrower than in other species. Vesica with a narrow portion of one strap terminating lateral to secondary gonopore, single blade of vesica robust, smoothly curved and gradually 
tapering, with semicircular dentate outgrowth (Figs 21, 22); secondary gonopore without adjacent sclerotized band, located on a broad membranous area.

Female. Coloration: As in male but general coloration of dorsum occasionally much paler, varying from dirty yellow to dark brown, basal part of second antennal segment always paler than incrassate dark brown apical part, calli usually with several dark brown, variously shaped marks. Structure: Total length $3.8-4.4$, body $2.8-3.1 \times$ as long as width of pronotum; Head: Vertex 2.0-2.2 $\times$ as wide as eye; second antennal segment distinctly incrassate, apical part about twice as wide as base and of same width as first segment, $0.9-1.0 \times$ as long as basal width of pronotum, 1.4-1.6 $\times$ as long as width of head. Thorax: Pronotum 1.9-2.0 $\times$ as wide as long; tarsus and claw as in males. Genitalia: As in Fig. 34.

Hosts and natural history. Collected from Caragana arborescens in Altay, C. frutex in Kazakhstan, C. bungei and $C$. spinosa (Fabaceae) in Mongolia. Kerzhner (1964) also reported $C$. balchaschensis, $C$. microphylla and $C$. pygmaea as hosts and noted that adults of $P$. caraganae live approximately two weeks.

Distribution. Widely distributed in the steppe zone of Russia, Eastern Ukraine and Kazakhstan, extending to Irkutsk Province, Republic of Buryatia, Republic of Tuva, and Mongolia in the East. Also reported from Tajikistan (Kerzhner, 1964).

Type material examined. Holotype: Russian Federation: Krasnoyarsk Terr.: Minusinsk, Tagarskiy Island, $53.7^{\circ} \mathrm{N}$, 91.68333ํㅡ, 10.vii.1936, A.K. Lukyanovich, $10^{\text {}}$ (AMNH_PBI 00222414). Paratypes: Kazakhstan: Almaty Prov.: Topolevka, E Sarkand, Dzhungarskiy Alatau, $45.4^{\circ} \mathrm{N}, 80.31666^{\circ} \mathrm{E}$, 07.vii.1957, I.M. Kerzhner, $1 \delta^{\dagger}$ (AMNH_PBI 00222427). Karaganda Prov.: Aktau Mt., $90 \mathrm{~km} \mathrm{~S}$ of Atasu [Zhana-Arka], $47.86666^{\circ} \mathrm{N}, 71.95^{\circ} \mathrm{E}, 29 . v i i .1960$, I.M. Kerzhner, Caragana frutex, 20 (AMNH_PBI 00222425, AMNH_PBI 00222426), 1 을 (AMNH_PBI 00222377). Koksengir Mt, $40 \mathrm{~km} \mathrm{~W}$ of Zhana-Arka [Atasu], $48.685^{\circ} \mathrm{N}, \quad 71.108^{\circ} \mathrm{E}, \quad 18 . v i i .1958$, Asanova, $10^{\pi}$ (AMNH PBI 00222422), 1 ( 9 (AMNH PBI 00222376). Kyzyltau Mt, $120 \mathrm{~km} \mathrm{~S}$ of Atasu [Zhana-Arka], $47.95861^{\circ} \mathrm{N}, 72.28139^{\circ} \mathrm{E}, 29 . v i i .1960$, I.M. Kerzhner, Caragana frutex, 2ㅇ (AMNH_PBI 00222423, AMNH_PBI 00222424). Russian Federation: Buryatia Rep.: Durenskaya [Dureny], 30 verst $\mathrm{E}$ of Kyakhta [Troitskosavsk], $50.316^{\circ} \mathrm{N}$, 106.915 ${ }^{\circ} \mathrm{E}$, 18.vii.1924, Vinogradov, $10^{\pi}$ (AMNH_PBI 00222431). Ust'-Kyakhta, bank of Selenge River, $50.5^{\circ} \mathrm{N}$, 106.26666 ${ }^{\circ}$ E, 16.vii.1928, A.K. Lukyanovich, 4 ㅇ (AMNH_PBI 00222462-AMNH_PBI 00222465). Krasnoyarsk Terr.: Minusinsk, Tagarskiy Island, $53.7^{\circ} \mathrm{N}, 91.68333^{\circ} \mathrm{E}, 10 . \mathrm{vii} .1936$, A.K. Lukyanovich, 70 (AMNH_PBI 00222415-AMNH_PBI 00222421). Tuva Rep.: Aryg-Uzyu S Shagonar, bank of UluKema River, $51.41666^{\circ} \mathrm{N}, \quad 92.58333^{\circ} \mathrm{E}, \quad$ 13.vii.1947, Cherepanov, 10 (AMNH_PBI 00222428), 19 (AMNH_PBI 00222459). Biche-alik River, Confluent of Buren River, 51.38333 ${ }^{\circ} \mathrm{N}, \quad 95.71666^{\circ} \mathrm{E}, \quad$ 18.viii.1948, Kalugin, 1 ㅇ (AMNH_PBI 00222460). Chaa-Khol Stream, right Confluent of Ulu-Khem River, $51.63333^{\circ} \mathrm{N}, 92.41666^{\circ} \mathrm{E}$, 29.vi.1949, Cherepanov, 1 ( (AMNH_PBI 00222461). Chadan, Basin of Khemchik River, $51.2833 \overline{3}^{\circ} \mathrm{N}, 91.58333^{\circ} \mathrm{E}$, 12.vii.1948, Kalugin, $10^{\circ}$ (AMNH_PBI 00222429). Khandagayty, NW Uspa-Nur Lake, $50.7166 \overline{6}^{\circ} \mathrm{N}, \quad 92.03333^{\circ} \mathrm{E}, \quad 20 . v i i .1948$, Cherepanov, $10^{\circ}$ (AMNH_PBI 00222430). Kyzyl, $51.7^{\circ} \mathrm{N}, \quad 94.38333^{\circ} \mathrm{E}$, 04.vii.1948, Cherepanov, 29 (AMNH_PBI 00222457, AMNH_PBI 00222458).
Other specimens examined. Mongolia: Central Aimak: $\mathrm{Nr}$ Songiin [Songino], SW of Ulaanbaatar, steppe, $47.81666^{\circ} \mathrm{N}$, 106.66666ํㅡ, 01.vii.1967, I.M. Kerzhner, Caragana bungei, $60^{\top}$ (AMNH PBI 00222435-AMNH PBI 00222439, AMNH PBI

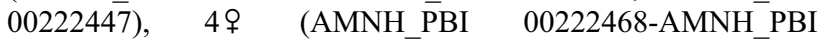
00222471). Dzavhan Aimak: $20 \mathrm{~km} \mathrm{~W}$ Somon Ältay [Bayan-ula], $49.7^{\circ} \mathrm{N}, 96.06666^{\circ} \mathrm{E} ， 02 . v i i .1968$, Kozlov，30 (AMNH_PBI 00222440, AMNH_PBI 00222441), 17 우 (AMNH_PBI 00222441-AMNH PBI 00222442, AMNH PBI 00222472-AMNH_PBI 00222473, AMNH_PBI 00222475AMNH_PBI 00222476, AMNH_PBI 00222476). Hovd Aimak: $15 \mathrm{~km} \mathrm{SW}$ of Kobdo, 48.08333 ${ }^{\circ} \mathrm{N}, 91.48333^{\circ} \mathrm{E}$, 08.vii.1980, I.M. Kerzhner, 20 (AMNH_PBI 00222446, AMNH_PBI 00222448), 12 (AMNH PBI 00222477, AMNH_PBI 00222479-AMNH_PBI 00222481) Caragana spinosa, 1 우 (AMNH_PBI 00222478). Altan-Hohiy Mts Range, $60 \mathrm{~km} \mathrm{~N}$ Myangat, $48.86666^{\circ} \mathrm{N}, 91.66666^{\circ} \mathrm{E}$, 04.viii.1970, A.F. Emeljanov, 29 (AMNH_PBI 00249003, AMNH_PBI 00249004). Ulyasutain gol River, $25 \mathrm{~km} \mathrm{~N}$ of Bulgan, $47.15^{\circ} \mathrm{N}, 93.6^{\circ} \mathrm{E}$, 31.vii.1970, A.F. Emeljanov, 39 (AMNH_PBI 00249005AMNH_PBI 00249007). Middle Govi Aimak: DelgerHangay-ula Mts, $48.2666^{\circ} \mathrm{N}, 109.31667^{\circ} \mathrm{E}, 25 . v i .1967$, I.M. Kerzhner, Caragana pygmaea, $10^{\dagger}$ (AMNH_PBI 00249002),

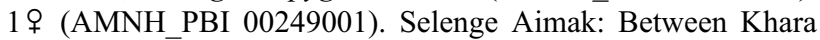
(= Boro?) and Sharyn Rivers, $49.607^{\circ} \mathrm{N}, 105.983^{\circ} \mathrm{E}$, Yakovlev coll., $1 \delta^{\top}$ (AMNH_PBI 00222432). Suhbaatar Aimak: 20 km SE of Barun-Urta, ${ }^{4} 46.553^{\circ} \mathrm{N}, 113.463^{\circ} \mathrm{E}, \quad 14 . v i i .1971$, I.M. Kerzhner, 5 ठ (AMNH_PBI 00249027, AMNH_PBI 00249028). $40 \mathrm{~km} \mathrm{SE}$ of Barun-Urt, $46.426^{\circ} \mathrm{N}, 113.644^{\circ} \mathrm{E}, 14 . v i i .1971$, I.M. Kerzhner, 3 ơ (AMNH_PBI 00249025, AMNH PBI 00249026), 11 (AMNH_PBI 00249022-AMNH_PBI 00249026). DzotolKhan-Ula Mt., $45.83333^{\circ} \mathrm{N}, 114.66667^{\circ} \mathrm{E}, 21 . v i i .1976$, I.M. Kerzhner, 60 (AMNH_PBI 00248994-AMNH_PBI 00248997),

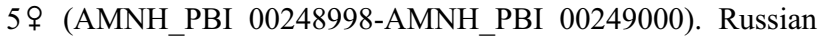
Federation: Altay Terr.: $20 \mathrm{~km}$ SE of Onguday, Central Altay, $50.65^{\circ} \mathrm{N}, 86.36666^{\circ} \mathrm{E}, 16 . v i i .1964$, I.M. Kerzhner, Caragana arborescens, $30^{\star}$ (AMNH PBI 00222433-AMNH PBI 00222434, AMNH_PBI 00222445), 2 우 (AMNH_PBI 00222466, AMNH_PBI 00222467); 15.vii.1964, I.M. Kerzhner, Caragana arborescens, 20 (AMNH_PBI 00222443, AMNH_PBI 00222474).

\section{Phaeochiton ebulum V.G. Putshkov, 1977}

Phaeochiton ebulum V.G. Putshkov, 1977: 370.

Figs 5-8, 27, 28, 31, 33

\section{Diagnosis}

Recognizable by its small size, generally uniform coloration, the long labium always reaching metacoxa, the brown simple setae distributed on the posterior two thirds to one half of the hemelytra, and the twin-bladed vesica with comparatively robust, apically rounded and distinctly incised smaller blade. Resembling $P$. alenae in external appearance, coloration, and structure of the vesica, but easily distinguished by the characters listed in the key to species.

\section{Description}

Male. Coloration: Variable (Figs 5-8). Dorsum and venter ranging from uniformly pale, whitish or dirty yellow, to olive brown, occasionally dark brown; pronotum, scutellum and basal part of hemelytra usually somewhat darker than remaining parts of dorsum; cuneal fracture in dark specimens with pale edging, exposed part of 
mesonotum sometimes with orange tinge at sides, membrane and veins uniformly pale brown, rarely veins partly whitish or dirty yellow; head, thorax, hemelytra, and all appendages uniformly colored, without dark markings, rarely apices of hind femora with minute and indistinct brown markings. Surface and vestiture: As in P. alenae, but brown simple setae distributed on posterior two thirds to one half of hemelytra, tibial spines pale brown to brown, medial spines of first antennal segment and apical spines of femur pale brown, almost pale in the palest specimens.

Structure: Total length $3.7-4.3$, body $3.0-3.6 \times$ as long as width of pronotum. Head: Vertex $1.8-2.0 \times$ as wide as eye; second antennal segment not incrassate, slightly wider than third, $0.8-1.0 \times$ as long as basal width of pronotum, 1.3-1.4 $\times$ as long as width of head, labium reaching to or slightly surpassing metacoxae. Thorax: Pronotum 2.0-2.3 $\times$ as wide as long; tarsus and claw as in generic description. Genitalia: Genital capsule as in generic description. Parameres: Right paramere comparatively short, $1.75 \times$ as long as wide; left paramere similar to that of $P$. alenae. Vesica with a portion of one strap terminating just before secondary gonopore (Figs 27, 28, 31 ), apically with two blades of unequal length, smaller blade straight, and rather robust, nearly as wide as larger blade at base, with distinctly pronounced incision at apex; secondary gonopore in lateral view with C-shaped sclerotized band proximally extending along apical edge of short portion of one strap.

Female. Structure: Body $2.7-3.0 \times$ as long as width of pronotum; total length 3.2-3.7. Head: Vertex 2.0-2.6 $\times$ as wide as eye; second antennal segment $0.8-0.9 \times$ as long as basal width of pronotum, $1.2-1.3 \times$ as long as width of head. Thorax: Pronotum 2.2-2.6 $\times$ as wide as long; tarsus and claw as in male. Genitalia: Bursa copulatrix as in Fig. 33.

Variability. All examined specimens from Kazakhstan have uniformly pale, whitish yellow dorsum, while populations from Eastern Ukraine and Altay are much darker, olive brown to pale brown. Specimens from Mongolia are intermediate in this respect, ranging in coloration of dorsum from dirty yellow to olive brown.

Hosts and natural history. The specimens were collected from Caragana frutex in Ukraine and Altay, $C$. balchaschensis in Kazakhstan, C. bungei, C. pygmaea, C. spinosa and Caragana sp. (Fabaceae) in Altay and Mongolia. According to observations of Putshkov (1977) in Eastern Ukraine, $P$. ebulum overwinters in the egg stage and develops into larvae in late April to early May. Adults emerge in late May to early June and die by mid to late June.

Distribution. Steppe zone of Ukraine, Kazakhstan, Mongolia, and adjacent localities of Altay Rep. (Russia).

Type material examined. Holotype: Ukraine: Streletskaya

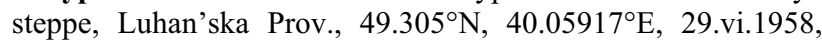
Putshkov, $1 \delta^{\dagger}$ (AMNH_PBI 00222137). Paratypes: Kazakhstan: Karaganda Prov.: $40 \mathrm{~km}$ S of Atasu [Zhana-Arka], $48.31666^{\circ} \mathrm{N}$, 71.66666 ${ }^{\circ}$ E, 24.vi.1960, I.M. Kerzhner, 50 ô (AMNH_PBI 00222144-AMNH_PBI 00222165, AMNH_PBI 00222228-
AMNH_PBI 00222232), 10 (AMNH_PBI 00222146-AMNH_PBI 00222151, AMNH_PBI 00222153, AMNH_PBI 00222155) Caragana balchaschensis, 1 ㅇ (AMNH_PBI 00222144). Mongolia: Hovd Aimak: Altan-Hohiy Mts Range, $60 \mathrm{~km} \mathrm{~N}$ Myangat, $48.86666^{\circ} \mathrm{N}, 91.66666^{\circ} \mathrm{E}$, 04.viii.1970, I.M. Kerzhner, 20 (AMNH_PBI 00222167, AMNH_PBI 00222168), 2 ㅇ (AMNH_PBI 00222233, AMNH_PBI 00222234) Caragana sp., 10 (AMNH_PBI 00222166), 1 ㅇ (AMNH PBI 00222235). Middle Govi Aimak: $20 \mathrm{~km} \mathrm{~W}$ Lus somon [T'sagaan-Ovoo], $45.506^{\circ} \mathrm{N}, 105.489^{\circ} \mathrm{E}$, 23.vii.1967, I.M. Kerzhner, Caragana pygmaea, $20^{\star}$ (AMNH_PBI 00222170, AMNH_PBI 00222171), 1 우 (AMNH_PBI 00222242). $25 \mathrm{~km}$ WSWW Mandalgovi, $45.7^{\circ} \mathrm{N}$, $105.95^{\circ} \mathrm{E}, 23 . v i i .1967$, I.M. Kerzhner, Caragana pygmaea, $10^{\star}$ (AMNH_PBI 00222169), 6이요 (AMNH_PBI 00222236-AMNH_PBI 00222241). Ukraine: Provalskaya Steppe, Luhan'ska Prov., 48.17194 ${ }^{\circ}, 39.855^{\circ}$ E, 12.vi.1958, Putshkov, 10 (AMNH_PBI 00222139), 1 우 (AMNH_PBI 00222139). Streletskaya steppe, Luhan'ska Prov., $49.305^{\circ} \mathrm{N}$, 40.05917E, 22.vi.1957, Putshkov, 40 (AMNH_PBI 00222141AMNH_PBI 00222143), 2ㅇ (AMNH_PBI 00222141, AMNH PBI 00222143); 29.vi.1958, Putshkov, $30^{\star}$ (AMNH_PBI 00222138, AMNH_PBI 00222140).

Other specimens examined. Kazakhstan: Karaganda Prov. $40 \mathrm{~km} \mathrm{~S}$ of Atasu [Zhana-Arka], $48.31666^{\circ} \mathrm{N}, 71.66666^{\circ} \mathrm{E}$, 21.vi.1960, I.M. Kerzhner, $17 \overbrace{}^{\Uparrow}$ (AMNH_PBI 00222172AMNH_PBI 00222188), 14우요 (AMNH PBI 00222244-AMNH_PBI 00222257) Caragana balchaschensis, 1 은 (AMNH_PBI 00222243); 02.vii.1960, I.M. Kerzhner, 18 우 (AMNH_PBI 00222259-AMNH_PBI 00222276) Caragana balchaschensis, 1 (AMNH_PBI 00222258). Mongolia: Dzavhan Aimak: $10 \mathrm{~km} \mathrm{~S}$ Mondoohoo [Tsagan-Khayrkhan], $49.3^{\circ} \mathrm{N}$, 94.23333ํㅡ, 12.viii.1970, Emeljanov, $10^{\star}$ (AMNH_PBI 00222189). Govialtay Aimak: $15 \mathrm{~km} \mathrm{~S}$ of Jargalant [Beger], $45.56666^{\circ} \mathrm{N}, 97.16666^{\circ} \mathrm{E}, 14 . v i i .1970$, I.M. Kerzhner, Caragana sp., 19 (AMNH_PBI 00222298). Hovd Aimak: 15 km $\mathrm{SW}$ of Kobdo, $48.08333^{\circ} \mathrm{N}, 91.48333^{\circ} \mathrm{E}$, 08.vii.1980, I.M. Kerzhner, 3 $0^{\star}$ (AMNH_PBI 00222294), 3 우 (AMNH_PBI 00222289) Caragana spinosa, 2 우 (AMNH_PBI 00222288). 5 $\mathrm{km}$ NW Uench, $46.081^{\circ} \mathrm{N}, 91.97^{\circ} \mathrm{E}, 25 . v i .1980$, I.M. Kerzhner, 40 (AMNH_PBI 00222195, AMNH_PBI 00222196), 1 \% (AMNH_PBI 00222290). Altan-Hohiy Mts Range, $60 \mathrm{~km} \mathrm{~N}$ Myangat, $48.86666^{\circ} \mathrm{N}, 91.66666^{\circ} \mathrm{E}, 04 . v i i .1970$, Narchuk, $50^{\star}$ (AMNH_PBI 00222199-AMNH_PBI 00222201, AMNH_PBI

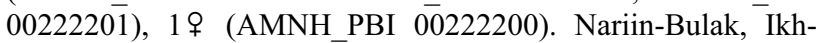
Khavtgiin-Nuru Mt. range, $45.056^{\circ} \mathrm{N}, 92.169^{\circ} \mathrm{E}$, 24.vii.1970, I.M. Kerzhner, Caragana sp., $30^{\star}$ (AMNH_PBI 00222197, AMNH_PBI 00222198), 6우 (AMNH_PBI 00222197, AMNH_PBI 00222293-AMNH_PBI 00222294); 24.vii.1970, Emeljanov, 20 (AMNH_PBI 00222190, AMNH_PBI

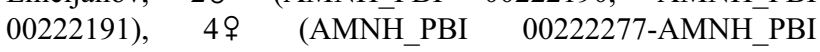
00222280); 24.vii.1970, Narchuk, 1 우 (AMNH_PBI 00222297) Caragana sp., 4 우 (AMNH_PBI 00222295, AMNH_PBI 00222296). Middle Govi Aimak: $25 \mathrm{~km}$ WSW Mandalgovi, $45.7^{\circ} \mathrm{N}, 105.95^{\circ} \mathrm{E}, 23 . v i i .1967$, I.M. Kerzhner, Caragana pygmaea, $10^{\dagger}$ (AMNH_PBI 00222193), 5우 (AMNH_PBI 00222283-AMNH_PBI 00222287). Delger-Hangay-ula Mts, $48.2666^{\circ} \mathrm{N}, 109.31667^{\circ} \mathrm{E}, 25 . v i i .1967$, I.M. Kerzhner, Caragana pygmaea, 10 (AMNH_PBI 00222192), 19 (AMNH_PBI 00222282); 25.vii.1967, Emeljanov, 1 우 (AMNH_PBI 00222281). Russian Federation: Altay Rep.: $20 \mathrm{~km}$ SE of Ongudai, $50.627^{\circ} \mathrm{N}, 86.34^{\circ} \mathrm{E}, 15$ vii. 1964 , I.M. Kerzhner, Caragana pygmaea, 10 (AMNH_PBI 00222382), 6 우 (AMNH_PBI 00222328-AMNH_PBI 00222333). Kosh-Agach, $49.98333^{\circ} \mathrm{N}$, 88.63333ํㅡ, 31.vii.1964, I.M. Kerzhner, 5 ㅇ (AMNH PBI 00222303-AMNH_PBI 00222307) Caragana spinosa, 10 
(AMNH PBI 00222380); 25.viii.1964, I.M. Kerzhner, Caragana bungei, 69 (AMNH PBI 00222323-AMNH PBI 00222327, AMNH_PBI 00222379); 05.vii.1964, I.M. Kerzhner, $10^{\star}$ (AMNH PBI $\overline{\mathrm{I}}$ 00222381) Caragana spinosa, $10^{\star}$ (AMNH_PBI 00222380); 10.vii.1964, I.M. Kerzhner, 14 ㅇ (AMNH_PBI 00222308-AMNH_PBI 00222316, AMNH_PBI 00222318-AMNH_PBI 00222322) Caragana spinosa, 1 우 (AMNH_PBI 00222317). Altay Terr.: Lebyazh'ye, $51.68333^{\circ} \mathrm{N}$, 80.83333 ${ }^{\circ} \mathrm{E}, \quad 06 . v i .1951, \quad$ Tamarina, 39 (AMNH PBI 00222300-AMNH_PBI 00222302), $10^{\star}$ (AMNH_PBI 00222203) Caragana frutex, 1 o (AMNH PBI 00222202), 1 우 (AMNH_PBI 00222299). Ukraine: Platy village [former Balta Uezd, Podolsk Government], 47.9372 N, 29.6194ㅌ, 23.v.1925, Ogloblin, 1 ㅇ (AMNH_PBI 00233601).

ACKNOWLEDGEMENTS. I am greatly indebted to I.M. Kerzhner (Zoological Institute, Russian Academy of Sciences), M.D. Schwartz (ECORC, Agriculture and Agri-Food, Ottawa, Canada), and R.T. Schuh (American Museum of Natural History) for comments on the manuscript. This paper is a contribution to the NSF Planetary Biodiversity Inventory grant (PBI) DEB-0316495 to R.T. Schuh, American Museum of Natural History, NY and Gerasimos Cassis, University of New South Wales, Sydney, Australia. The equipment used during the work was funded by the Russian Foundation for Basic Research, project No. 08-04-00295-a and "Leading scientific schools" project No. NSh-963.2008.4. The collection of Zoological Institute, St. Petersburg, is supported by Rosnauka for UFC No. 2-2.20.

\section{REFERENCES}

Carvalho J.C.M. 1955: Keys to the genera of Miridae of the world (Hemiptera). Bol. Mus. Paraen. E. Goeldi 11(2): $1-151$.

KERZHNER I.M. 1962: Materials on the taxonomy of capsid bugs (Hemiptera - Miridae) in the fauna of the USSR. Entomol. Obozr. 41: 372-387 [in Russian].

KERZHNER I.M. 1964: New and little-known bugs (Heteroptera) from Kazakhstan and other regions of the USSR. Trud. Zool. Inst. Akad. Nauk SSSR 34: 113-130 [in Russian].
Kerzhner I.M. \& Josifov M. 1999: Cimicomorpha II. Miridae. In Aukema B. \& Rieger K. (eds): Catalogue of the Heteroptera of the Palaearctic Region. Vol. 3. The Netherlands Entomological Society, Amsterdam, 577 pp.

Kerzhner I.M. \& Matoce A. 1994: Type specimens of Palaearctic Miridae and Nabidae in the collection of the Muséum National d'Histoire Naturelle, Paris (Heteroptera). Zoosyst. Ross. 3: 55-68.

Pagola-Carte S., Zabalegui I. \& Ribes J. 2006: Miridae (Hemiptera: Heteroptera) de los Parques Naturales de Aralar ó Izki (País Vasco, norte de la Península Ibérica). Heteropt. Rev. Entomol. 6: 105-135.

Putshkov V.G. 1977: New and little-known mirid bugs (Heteroptera, Miridae) from Mongolia and Soviet Central Asia. Entomol. Obozr. 56: 360-374 [in Russian].

Stonedahl G.M. 1990: Revision and cladistic analysis of the Holarctic genus Atractotomus Fieber (Heteroptera: Miridae: Phylinae). Bull. Am. Mus. Nat. Hist. 198: 1-88.

WAGNER E. 1952: 41-Teil-Blindwanzen oder Miriden. In Dahl F. (ed.): Die Tierwelt Deutschlands und der angrnzenden Meersteile nach ihren Merkmalen und nach ihrer Lebensweise. G. Fischer, Jena, 218 pp.

WAGNer E. 1960: Beitrag zur Systematik der Gattung Atractotomus Fiber, 1858 (Hem. Het. Miridae). Trab. Mus. Zool. N. S. (Zool.) (Barcelona) 2(3): 2-4.

Wagner E. 1975: Die Miridae Hahn, 1831, des Mittelmeerraumes und der Makaronesischen Inseln (Hemiptera, Heteroptera). Teil 3. Entomol. Abh. (Suppl.) 40: ii +483.

Wagner E. \& Weber H.H. 1964: Héteroptères Miridae. In: Faune de France. Vol. 67. Paris, 592 pp.

Wyniger D. 2004: Taxonomy and Phylogeny of the Central European Bug Genus Psallus (Hemiptera, Miridae) and Faunistics of the Terrestrial Heteroptera of Basel and Surroundings (Hemiptera). PhD thesis, Philosophisch-Naturwissenschaftlichen Fakultät der Universität Basel, 285 pp.

Received March 3, 2008; revised and accepted April 12, 2008 